\title{
Knowledge, Preventive Practices, and Depression Among Chinese University Students in Korea and China During the COVID-19 Pandemic: An Online Cross-sectional Study
}

Research article

Keywords:

Posted Date: March 8th, 2021

DOl: https://doi.org/10.21203/rs.3.rs-48092/v6

License: (1) This work is licensed under a Creative Commons Attribution 4.0 International License. Read Full License 


\section{Abstract}

The authors have requested that this preprint be withdrawn due to erroneous posting.

\section{Full Text}

The authors have withdrawn this preprint from Research Square. 